\title{
直投粒子群の流動・拡散現象と 乱れ特性に関する研究 SWARM OF PARTICLES AND ITS TURBULENCE CHARACTERISTICS
}

\author{
秋山 壽一郎 ${ }^{1} \cdot$ 山下 直樹 $^{2} \cdot$ 浦 勝 $^{3} \cdot$ 陶山 正治 $^{4}$ \\ Juichiro AKIYAMA, Naoki YAMASHITA, Masaru URA and Masaharu SUYAMA \\ ${ }^{1}$ 正会員 Ph.D. 九州工業大学教授 工学部建設社会工学科（广804-8550北九州市戸畑区仙水町 1-1） \\ 2学生員 九州工業大学大学院 工学研究科博士前期課程 (同上) \\ 3正会員 工博 九州工業大学教授 工学部建設社会工学科 (同上) \\ ${ }^{4}$ 工修 大成建設株式会社 名古屋支店（テ450-5047名古屋市中村区名駅1-1-4）
}

\begin{abstract}
Swarms of particles, produced by direct dumping of particles into a quiescent body of water, are investigated experimentally. A series of laboratory experiments is conducted, varying size as well as amount of dumping particles. It is found that such main flow characteristics of particle clouds as half-width, mean buoyancy force and falling velocity can be adequately described by a single-phase Boussinesq thermal theory as long as particle clouds remain in thermal-like phase. A transitional condition from the thermal-like phase to the free settling-like phase of particle clouds is roughly estimated semi-theoretically. It is also shown that turbulent intensity along the main axis of the particle thermal is proportional to its falling velocity, and its ratio to falling velocity of a particle is almost independent of its size.
\end{abstract}

Key Words : Turbidity,particle thermal, thermal theory, turbulence

\section{1. はじめに}

人工島の建設などを目的とした水域への土砂直投 工では水表面付近から多量の土砂が投下されるため、 大規模な污濁が発生することが大きな問題である。 このような污濁拡散現象は、投下点近くの局所的な 土砂の落下運動とそれによって誘起された周囲流体 の流動が重要となるNear Field領域と主に潮流など の周囲流体環境が支配的な乱流拡散過程である Far Field領域に大きく分けられる。このNear Field領 域における密度流的な污濁拡散過程は、局所的な污 濁拡散防止対策と直接関係しているだけではなく、 広域的な污濁拡散現象の初期条件でもあるので、そ の特性を把握しておくことは重要である。

そのような理由で、土砂直投工に起因する局所的 な污濁拡散現象を解明・予測する試夕が、数值解析 ${ }^{1-5)}$ や乱流サーマル理論 ${ }^{-9)} に$ 基づき重ねられている。 数值解析は周囲流体の環境条件を考慮できることや 粒子群の落下挙動から底面衝突後の挙動までを一貫 して解析できることなど、複雑な状況に対処できる ことが大きな利点であるが、直投工で発生する落下 粒子群は高濃度の固一液混相乱流現象であるため、 最新の数値解析技術をもってしても粒子の濃度や絶
対量などに関して適用上の制約を強く受ける。一方、 乱流サーマル理論は積乱雲の形成やガスや火薬の爆 発など大気中の熱対流現象を対象として構築されて きたものであるが10 11)、土砂直投工では水深が 15 20m程度の比較的浅い水域に数千 $\mathrm{m}^{3}$ という多 量の土砂が投下されるため、粒子サーマルとして落 下し、その状態で底面に衝突することから、土砂直 投に伴う局所的な污濁拡散現象を解析する手段とし ても最近用いられている。闪 例えば、玉井ら ${ }^{8)}$ は、 粒径が大きく投下量が少ない場合には個々の粒子の 自由沈降的な落下形態となり、粒径が小さく投下量 が多い場合には粒子群として流動する乱流サーマル 的な落下形態となることを実験的に明かにした上で、 Baines \& Hopfinger ${ }^{11}$ による単相の非ブスネスク サーマル理論を発展させ、自由沈降的落下挙動と乱 流サーマル的落下挙動を統一的に説明するための固 一液混相サーマル理論を提案している。このような サーマル理論は形状の相似性を基本仮定とするため 複雑な状況には適用できないが、単純な状況であれ ば主要な流動特性を簡便に記述できることが大きな 利点である。

落下粒子群に対して乱流サーマル理論がどの程度 まで適用できるのかについて調べた研究としては、 
先述したもの8)がある。この固-液混相サーマル理論 の妥当性はさておき、その基礎となっている Baines \& Hopfinger ${ }^{11)}$ の単相の非ブシネスクサー マル理論では連行係数の概念が通常の定義とは大き く異なっているのみならず、キネマティクな関係式 である体積保存則にダイナミックな諸量が考慮され なければならない根拠も明確ではない。このような 理由もあり、これまでの研究で単相サーマルと粒子 サーマルとの流動特性の違いについて明確な見解が 得られているわけではない。

本研究は、以上のような背景を踏まえ、粒子サー マル的な落下形態における落下粒子群の基本的な流 動特性を明らかにすることを試みたものである。ま ず、単相のブシネスクと非ブシネスクサーマル理論 について検討を加え、ブスネスクサーマル理論から 得られる近似解の妥当性を示す。次に、落下粒子群 の粒子サーマル的な落下形態から自由沈降的な落下 形態への遷移点について大まかな目安を示した上で、 乱流サーマル的な落下形態における落下粒子群の最 大拡がり幅、平均浮力および落下速度が単相ブシネ スクサーマル理論で記述できることを明らかにする。 最後に、落下粒子群の乱れ特性についても検討を加 える。

\section{2. 実験}

実験装置は、両面アクリル製の水槽(長さ7.5m、 深さ $1.0 \mathrm{~m}$ 、幅 $0.1 \mathrm{~m})$ に流入装置を取り付けたもの で、流入装置より水深h、密度 $\rho_{\mathrm{a}}$ の静止した淡水中 にガラスビーズ粒子あるいは振る振い分けしたケイ 砂(粒径d、水中比重s) と水を混合した濁水を単位幅 当たりの初期総浮力 $2 \mathrm{~W}_{0}\left(=2 \mathrm{c}_{0} \mathrm{sg} \mathrm{A}_{0}\right)$ で水表面より直 投することで落下粒子群を発生させた。ここに、 $\mathrm{C}_{0}$ は濁水の初期体積濃度 $\left(=A_{p} / A_{0}\right) 、 A_{0}$ は初期単位幅 体積、 $\mathrm{A}_{\mathrm{p}}$ は空隙を除いた粒子の初期単位幅体積、 $\mathrm{g}$ は重力加速度である。

実験条件は表- 1 に示す通りであり、CASE A と CASE Bの 2 通りの実験を行った。CASE Aではd とW。をそれぞれ 4 通りに変化させ、CCDカメラで 撮影した落下粒子群の流動状況をコンピュター制御 が可能なVTRに収録し、それらの画像をパソコン に取り込み、画像解析することによって、落下粒子 群の落下速度Vおよび形状を求めた。一方、CASE Bではd 2 通りに変化させ、電磁流速計を落下粒 子群の中心軸上に設置しオイラ一的に落下方向の 3 点で測定を行った。流れの再現性は比較的良好であっ たが、いずれの計測においても同一条件下で5回の 繰り返し実験を行い、データの信頼性を高めた。図 -1 は落下粒子群の流動状況の一例であるが、左右 ほぼ対称な循環流より構成される落下粒子群が、周
表-1 実験条件

\begin{tabular}{|c|c|c|c|c|c|c|}
\hline CASE & $\begin{array}{l}\text { 中央粒径 } \\
\mathrm{d}(\mathrm{cm})\end{array}$ & $\begin{array}{c}\text { 水中比重 } \\
\mathrm{S}\end{array}$ & $\begin{array}{l}\text { 浱度 } \\
\mathrm{C}(\%)\end{array}$ & $\begin{array}{c}\text { 相対密度差 } \\
\varepsilon_{0}\end{array}$ & $\begin{array}{c}\text { 初期単位蝠体積 } \\
\mathrm{A}_{0}\left(\mathrm{~cm}^{2}\right)\end{array}$ & $\begin{array}{l}\text { 初期総浮力 } \\
\mathrm{W}_{0}\left(\mathrm{~cm}^{3} / \mathrm{s}^{2}\right)\end{array}$ \\
\hline$A-1-1$ & \multirow{4}{*}{0.0044} & \multirow{16}{*}{1.47} & 16.1 & 0.237 & 12.5 & 2900 \\
\hline$A-1-2$ & & & 16.3 & 0.239 & 20.9 & 4900 \\
\hline$A-1-3$ & & & 19.9 & 0.292 & 24.0 & 6860 \\
\hline$A-1-4$ & & & 16.4 & 0.241 & 37.65 & 8900 \\
\hline$A-2-1$ & \multirow{4}{*}{0.0088} & & 8.7 & 0.128 & 23.05 & 2900 \\
\hline$A-2-2$ & & & 14.7 & 0.217 & 23.05 & 4900 \\
\hline A-2-3 & & & 12.6 & 0.186 & 37.65 & 6860 \\
\hline A-2-4 & & & 16.3 & 0.241 & 37.65 & 8900 \\
\hline$A-3-1$ & \multirow{4}{*}{0.0109} & & 8.6 & 0.128 & 23.05 & 2900 \\
\hline$A-3-2$ & & & 14.5 & 0.217 & 23.05 & 4900 \\
\hline$A-3-3$ & & & 12.5 & 0.186 & 37.65 & 6860 \\
\hline$A-3-4$ & & & 16.2 & 0.241 & 37.65 & 8900 \\
\hline$A-4-1$ & \multirow{4}{*}{0.0165} & & 8.4 & 0.128 & 23.05 & 2900 \\
\hline$A-4-2$ & & & 14.2 & 0.217 & 23.05 & 4900 \\
\hline$A-4-3$ & & & 12.2 & 0.186 & 37.65 & 6860 \\
\hline A-4-4 & & & 15.8 & 0.241 & 37.65 & 8900 \\
\hline B-1 & 0.0165 & 1.47 & 8.4 & 0.128 & 23.05 & 2900 \\
\hline B-2 & 0.027 & 1.65 & 21.2 & 0.3498 & 7.3 & 2500 \\
\hline
\end{tabular}

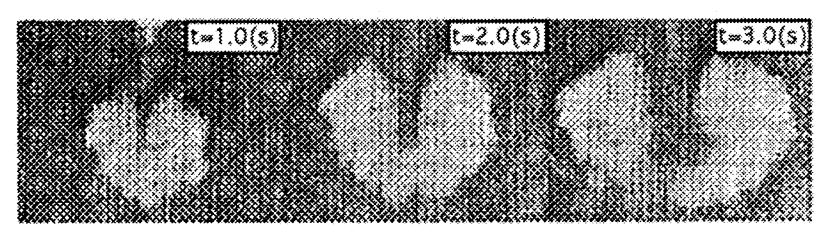

図-1＼cjkstart落下粒子群の流動状況(CASEA-4-3)

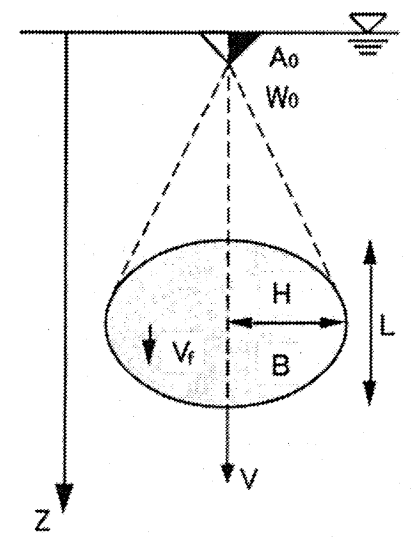

図-2 流れの定義図

囲流体を連行しながらほぼ相似な形状を保ちつつ流 動・拡散していくことがわかる。この観測結果に基 づき、落下粒子群を図-2のようにモデル化する。

\section{3. 実験結果}

本研究で対象とする落下粒子群は高濃度の固-液 混相乱流サーマル現象であるが、本論文の「補足」 で示した単相乱流サーマル理論によると、ブシネス クサーマルと非ブシネスクサーマルとでは落下速度 Vのみ異なり、その違いは投入点のごく近傍に限ら 
れる。また、ブシネスクサーマルと非ブシネスクサー マルの理論解は異なるが、投入点から少し離れたと ころでは、同一の近似解で表すことができる。

$\mathrm{W}_{0}=588 \mathrm{~cm}^{3} / \mathrm{s}^{2}$ の場合の単相のブシネスクサーマ ルと非ブシネスクサーマルの数値解、理論解および 近似解について比較検討したものが図-3である。 図- 3 aは実験值 と数值解の比較であり、これより 投下点のごく近傍を除き、両サーマル理論は同様な 結果を与えることがわかる。また、実験值とも良好 に一致していることも確認できる。图- 3 bは両サー マル理論の理論解と数值解を、図- $3 \mathrm{c}$ は近似解之 数値解を比較検討したものである。これらより、両 サーマル理論の理論解が正しいこと、投入点付近を 除いたほぼ全域で近似解が成立することなどが確認 できる。なお、「補足」で示した抵抗係数を考慮し たブシネスクおよび非ブシネスクサーマルの理論解 は本研究で初めて示されたものである。

以上のような検討結果を踏まえ、落下粒子群の流 動・拡散プロセスを記述する手段として、式(1)〜 (3)の近似解を採用する。紙面の都合で詳細は省略 するが、これらは「補足」で示した理論解の近似操 作を行うことて簡単に得ることができる。あるいは、 サーマルのOverall - Richardson数が落下方向に不 変であるとの条件を用いて求めることもできる9)。 また、図-3から明らかなように理論解での żはで ほぼ置き換えることができる。

投下条件 $\left(\mathrm{A}_{0} 、 \mathrm{~W}_{0}\right)$ の影響を取除くために、これら の諸量で無次元化した落下粒子群の無次元最大層厚 $\mathrm{H}^{*}\left(=\mathrm{H} / \mathrm{A}_{0}{ }^{1 / 2}\right)$ 、無次元平均浮力 $\mathrm{B}^{*}\left(=\mathrm{B} / \mathrm{B}_{0}\right)$ 、無次元 落下速度 $\mathrm{V}^{*}\left(=\mathrm{V} / \mathrm{V}_{0}\right)$ および無次元落下距離 $Z^{*}(=\mathrm{z} /$ $\left.\mathrm{A}_{0}{ }^{1 / 2}\right)$ を導入する。ここで、 $\mathrm{V}_{0}=\left(\mathrm{c}_{0} \mathrm{sgW}\right)^{1 / 4}$ あるい は $\left(\mathrm{W}_{0}{ }^{2} / \mathrm{A}_{0}\right)^{1 / 4} 、 \mathrm{~B}_{0}=\mathrm{W}_{0} / \mathrm{A}_{0}$ である。なお、式(1)〜 (3)中の係数 $K_{1}$ は式(4)〜 (6)で与えられる。

$$
\begin{gathered}
\mathrm{H}^{*}=\mathrm{K}_{1} \mathrm{Z}^{*}(1) ; \mathrm{B}^{*}=\mathrm{K}_{2} \mathrm{z}^{*-2}(2) ; \mathrm{V}^{*}=\mathrm{K}_{3} \mathrm{z}^{*-1 / 2}(3) \\
\mathrm{K}_{1}=\frac{\left(\mathrm{S}_{1} / \mathrm{S}_{2}\right) \sqrt{\mathrm{F}} \mathrm{E}_{\mathrm{d}}}{2} \\
\mathrm{~K}_{2}=\frac{\left(\mathrm{F} / \mathrm{S}_{1}\right)}{\left\{\left(\mathrm{S}_{1} / \mathrm{S}_{2}\right) \sqrt{\mathrm{FE}} \mathrm{d}_{\mathrm{d}} / 2\right\}^{2}} \\
\mathrm{~K}_{3}=\frac{\left[1 /\left\{(3 / 4)\left(1+\mathrm{A}_{\mathrm{m}}\right) \mathrm{S}_{2}\left(\mathrm{E}_{\mathrm{d}} / \sqrt{\mathrm{F}}\right)+\mathrm{C}_{\mathrm{d}}\right\}\right]^{1 / 2}}{\left\{\left(\mathrm{~S}_{1} / \mathrm{S}_{2}\right) \sqrt{\mathrm{F}} \mathrm{E}_{\mathrm{d}} / 2\right\}^{1 / 2}}
\end{gathered}
$$

式(4)〜(6)中の各パラメターの定義は、「補足」 に示す通りである。以上の近似解より、単相の乱流 サーマルでは $\mathrm{H}^{*} \propto \mathrm{Z}^{*} 、 \mathrm{~B}^{*} \propto \mathrm{Z}^{*-2}$ およびV ${ }^{*} \propto \mathrm{Z}^{*-1 / 2}$ なる関係が成立することがわかる。図-4は本研究 で得られた落下粒子群の各無次元特性量と $z$ との関 係を調べたものである。これより、落下粒子群に対

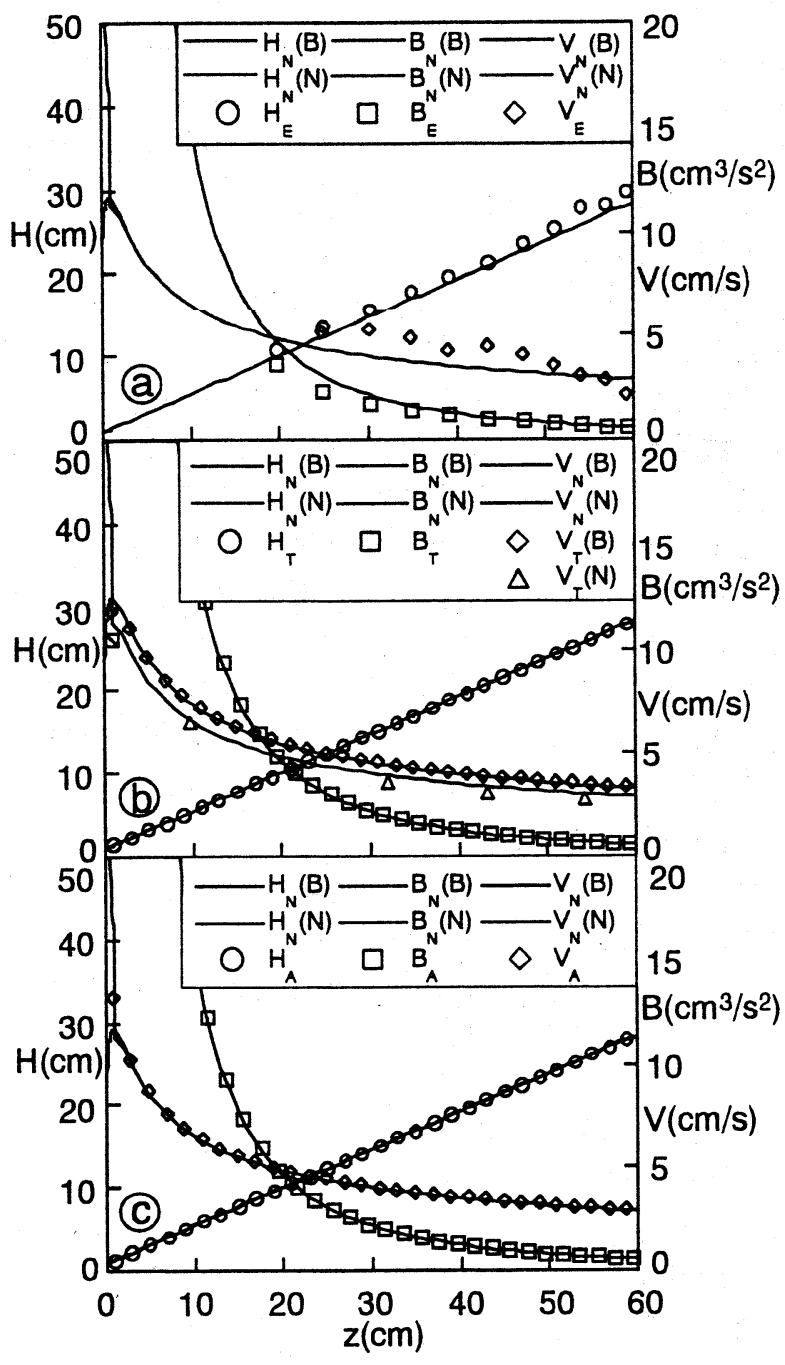

図-3 単相プシネスク、非プシネスクサーマル理論の検 証(a:実験值と数値解の比較、b:理論解と数值解、 $\mathrm{c}$ :近似解と数值解を比較)

しても式(4)〜(6)の関係が成立しており、本研究で 得られたデータが粒子サーマル的な落下形態に属し ていることが確認できる。

そこで、粒子サーマル的な落下形態と自由沈降的 な落下形態との大まかな遷移条件を調べる目的で、 粒子群の落下速度Vを個々の粒子の沈降速度 $\mathrm{V}_{\mathrm{f}}$ で無 次元化した速度比 $\mathrm{V} / \mathrm{V}_{\mathrm{f}}$ と無次元落下距離 ${ }^{*}$ との関 係をプロットしたものが図- 5 である。同図より、 すべてのデータが $/ \mathrm{V}_{\mathrm{f}} \geqq 1.0$ の範囲に存在しており、 粒子群の落下速度は個々の粒子の沈降速度よりも数 倍から数10倍大きいことがまずわかる。

粒子サーマル的な落下形態では式(3)の関係が成 立し、 $\mathrm{V}_{0}=\left(\mathrm{W}_{0}{ }^{2} / \mathrm{A}_{0}\right)^{1 / 4}$ であることを考慮すると、 $\mathrm{V} / \mathrm{V}_{\mathrm{f}}=\left[\left(\mathrm{W}_{0}{ }^{2} / \mathrm{A}_{0}\right)^{1 / 4} / \mathrm{V}_{\mathrm{f}}\right] \mathrm{K}_{3 \mathrm{P}} Z^{*-1 / 2}$ なる関係が得られ る。一方、本研究で用いた粒子粒径の範囲では近似 的に $\mathrm{V}_{\mathrm{f}} \propto \mathrm{d}^{2}$ なる関係が成立するので、粒子 Rey nolds 数 $\mathrm{R}_{\mathrm{p}}\left(=\mathrm{dV} \mathrm{f}_{\mathrm{f}} / \nu\right)$ は無次元表示した沈降速度 を用いると、 $\mathrm{R}_{\mathrm{p}}=(\alpha \mathrm{sg} \nu)^{-1 / 2} \mathrm{~V}_{\mathrm{f}}^{3 / 2}$ のようになる。こ 
こで、 $\alpha$ は粒子の沈降速度に関する無次元の定数で ある。いま、サーマル的な落下形態から自由沈降的 な落下形態への遷移がV $/ \mathrm{V}_{\mathrm{f}} \fallingdotseq 1.0$ で起るとすると、 これに対応する $z^{*}$ は $z^{*}{ }_{1.0} \fallingdotseq \beta \mathrm{R}_{\mathrm{p}}^{-4 / 3}$ なる関係を満足す る。ここに、 $\beta=(\alpha \mathrm{sg} \nu)^{-2 / 3}\left(\mathrm{~W}_{0}{ }^{2} / \mathrm{A}_{0}\right)^{1 / 2}\left(\mathrm{~K}_{3 \mathrm{P}}\right)^{2}$ であ る。後述するように今回の実験条件では $\mathrm{K}_{3 \mathrm{P}} \fallingdotseq 0.82$ なる一定值であるので、 $z_{1.0}^{*} \fallingdotseq \beta \mathrm{R}_{\mathrm{P}}^{-4 / 3}$ なる関係が 得られる。 $Z_{1.0}^{*}$ とR $R_{p}$ との関係を調べたものが図- 6 である。これより、上述した関係が確かに成立して おり、粒子サーマル的な落下形態と自由沈降的な落 下形態との大まかな遷移条件は $z^{*}{ }_{1.0} \fallingdotseq 900 \mathrm{R}_{\mathrm{p}}^{-4 / 3}$ のよ うになると考えられる。上述した関係によれば、一 般的に $\beta$ は投下粒子の性質 と投下量に依存すること になるが、粒子の比重は大きく変化するわけではな く、投下量も $\left(\mathrm{W}_{0}{ }^{2} / \mathrm{A}_{0}\right)^{1 / 2} \propto \mathrm{A}_{0}{ }^{1 / 2}$ であるので $\mathrm{A}_{0}$ の絶 対量よりその影響は小さい。加えて、本実験では実 験条件の範囲が比較的狭いために、 $\beta$ をほぼ一定值 として表現することが可能となっていると考えられ る。なお、 $z_{1.0}^{*}$ が1.0になる程度まで乱流サーマル 的な落下形態における落下粒子群のデータを得よう とすると、粒子粒径と投下量を極めて大きくする必 要があり、それに伴い周囲水水深も現行のものより かなり大きくしなければならない。そのためには、 相当に水深が深い水槽を用いる必要があり、このよ うな実験上の強い制約も受けることを指摘しておく。

図- 4 で見たように無次元落下距離Z゙との関係に おいて単相サーマルの関係に従うので、粒子サーマ ル的な落下形態における落下粒子群の係数を $\mathrm{K}_{\mathrm{ip}}$ と 表示する。 $\mathrm{K}_{\mathrm{iP}}$ はR $\mathrm{R}_{\mathrm{p}}$ の弱い関数と考えられたが ${ }^{22)}$ 、 同程度の粒径であっても今回のように投下量が多い 場合は $\mathrm{K}_{\mathrm{ip}}$ は $\mathrm{R}_{\mathrm{p}}$ の影響をほとんど受けず、その関係 は図-7のようになり、 $\mathrm{K}_{1 \mathrm{P}} \fallingdotseq 0.65 、 \mathrm{~K}_{2 \mathrm{P}} \fallingdotseq 2.10$ 、 $\mathrm{K}_{3 \mathrm{P}} \fallingdotseq 0.82$ で近似できる。一方、 $\mathrm{W}_{0}=$ $150 \sim 4900 \mathrm{~cm}^{3} / \mathrm{s}^{2}$ の範囲での塩水を用いた単相サー マルの $\mathrm{K}_{1}$ は、 $\mathrm{K}_{1} \fallingdotseq 0.50 、 \mathrm{~K}_{2} \fallingdotseq 2.10 、 \mathrm{~K}_{3} \fallingdotseq 0.90$ であ るので ${ }^{13)}$ 、両者の係数值にやや違いが生じているこ とがわかる。つまり、粒子サーマル的な落下形態に おける落下粒子群と単相サーマルの違いは、乱流サー マル理論では係数原を介して現れる。

そこで、このような係数値の違いがどのようにし て生じたのかについて検討するために、落下粒子群 から得られた式(4)〜(6) 中の各パラメターの值を用 いてK マルの各パラメターの値は、 $\mathrm{F} \fallingdotseq 0.63 、 \mathrm{~S}_{1} \fallingdotseq 0.79$ 、 $\mathrm{S}_{2} \fallingdotseq 2.25 、 \mathrm{E}_{\mathrm{d}} \fallingdotseq 0.40$ であり ${ }^{13)}$ 、落下粒子群では $\mathrm{F}_{\mathrm{p}} \fallingdotseq$ $0.67 、 \mathrm{~S}_{1 \mathrm{P}} \fallingdotseq 0.79 、 \mathrm{~S}_{2 \mathrm{P}} \fallingdotseq 2.32 、 \mathrm{E}_{\mathrm{dP}} \fallingdotseq 0.53$ である。 両者を比較すると、両者の違いはFと $\mathrm{E}_{\mathrm{d}}$ で著しいこ とがわかる。これらの落下粒子群の值と単相サーマ ル理論との比較より得られた抵抗係数值 $\mathrm{C}_{\mathrm{d}} \fallingdotseq 0.5$ を 式(4)〜(6)に代入して得られる係数を $\mathrm{K}_{\mathrm{iP}}$ ' と表示す ると、 $\mathrm{K}_{1 \mathrm{P}}{ }^{\prime} \fallingdotseq 0.65 、 \mathrm{~K}_{2 \mathrm{P}}{ }^{\prime} \fallingdotseq 2.0 、 \mathrm{~K}_{3 \mathrm{P}}{ }^{\prime} \fallingdotseq 0.8$ とな

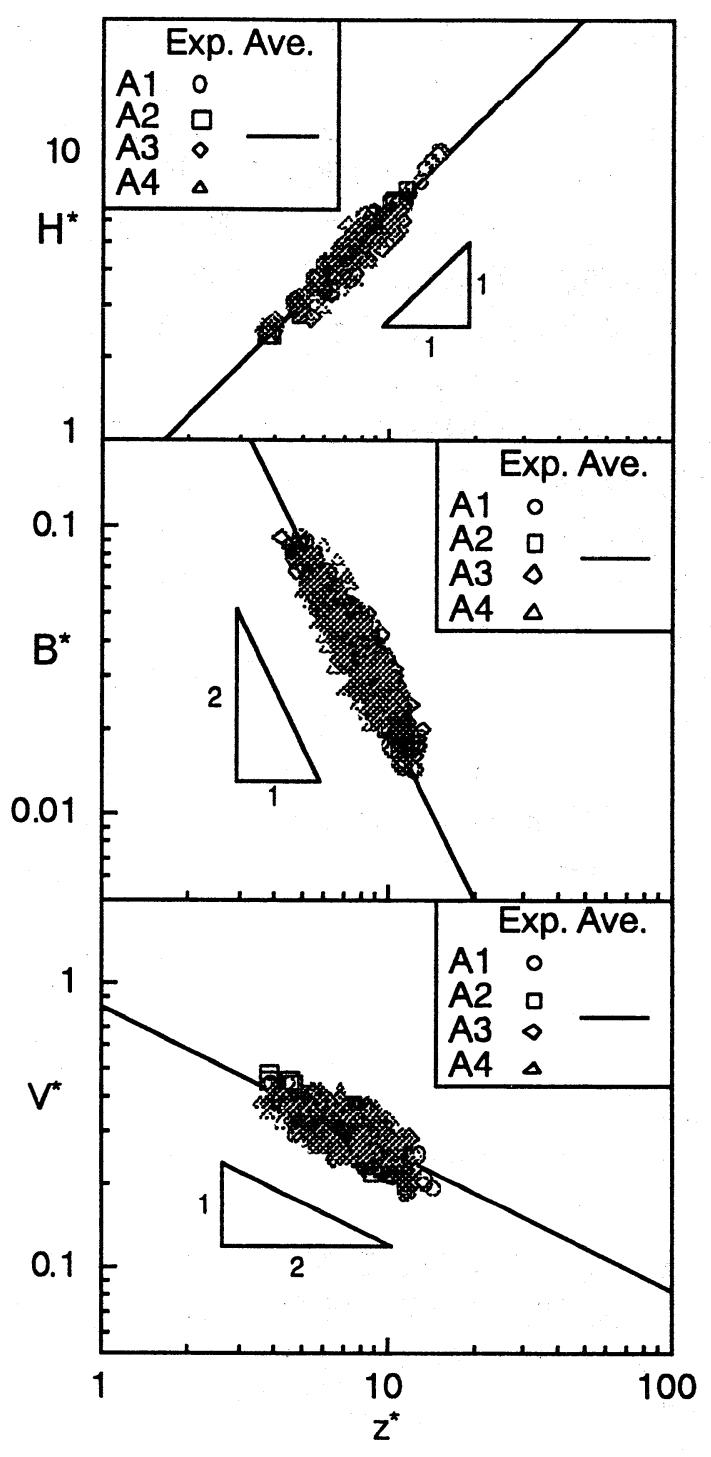

图-4 落下粒子群の無次元特性量 $\left(\mathrm{H}^{*}, \mathrm{~B}^{*}, \mathrm{~V}^{*}\right)$ と 無次元落下距離 $Z *$ との関係

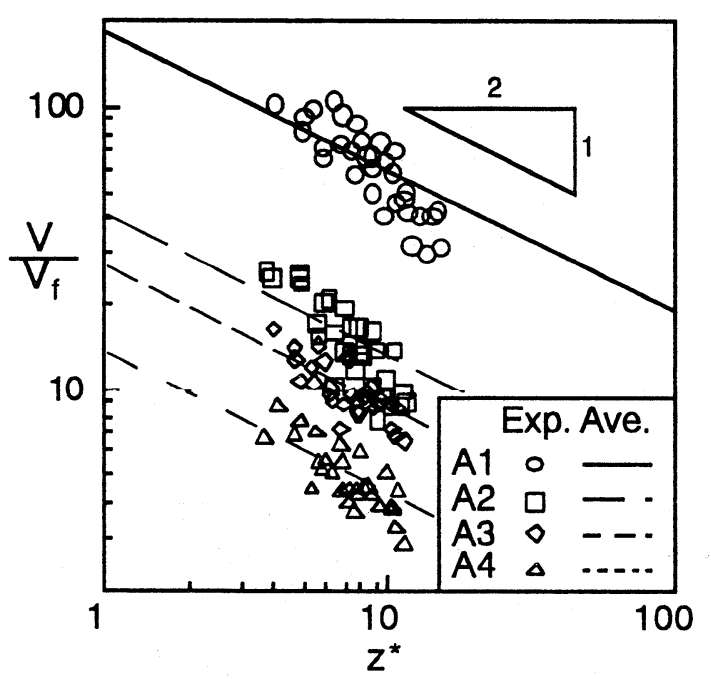

図-5 無次元落下速度 $V / V_{f}$ と無次元落下距離 $Z^{*}$ との関係 
り、 $\mathrm{K}_{\mathrm{p}}$ とほぼ同様の値となる。これより、粒子サー マルの係数も式(4)〜 (6)で与えられ、粒子サーマル と単相サーマルのFと $\mathrm{E}_{\mathrm{d}}$ の值が異なることが、 $\mathrm{K}_{1}$ と $\mathrm{K}_{1 \mathrm{P}}$ の違いを生じていることが確認できる。これは、

玉井 ら) $^{8}$ が乱流サーマル的な落下挙動を示す落下粒 子群の流動特性が連行係数などによって変化すると 指摘していることを定量的に示したものである。

最後に、CASE Bの実験結果に基づき、粒子サ一 マル的な落下形態における落下粒子群の乱れの状態 について検討を加える。図- 8 は、落下粒子群の中 心軸上の流速の時系列より得られた最大流速 $\mathrm{v}$ と最 大流速前後のサンプリング間隔 $\Delta t=0.15 \mathrm{~s}$ の乱れ強 度 $\left(\mathrm{v}^{\prime 2}\right)^{0.5}$ を落下粒子群の代表速度スケールV 0 で正規 化した速度比 $\mathrm{v} / \mathrm{V}_{0}$ と $\left(\mathrm{v}^{\prime 2}\right)^{0.5} / \mathrm{V}_{0}$ とz* との関係につい て調べたものである。なお、 $\Delta t=0.10 〜 0.25$ の範囲

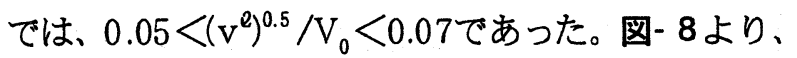
やや散らばりは認められるものの、粒子群の落下速 度 $\mathrm{V}$ と同様に、いずれの流速比も $z^{*} の-1 / 2$ 乗に比例 することが確認できる。ただし、ぞが一番大きいデー タはこの関係に従っていないが、これまでの一連の 研究を通じサーマル塊の下端が水槽底面に近づくと、 $-1 / 2$ 乗則より小さくなることが塩水サーマルでも 確認されており、粒子サーマルに固有の現象ではな い。さらに、いくつかの速度比について検討してみ ると、CASE B-1で $\left(\mathrm{v}^{\prime 2}\right)^{0.5} / \mathrm{v} \fallingdotseq 0.060 、 \mathrm{v} / \mathrm{V} \fallingdotseq 2.8$ 、 $\left(\mathrm{v}^{\prime 2}\right)^{0.5} / \mathrm{V}_{\mathrm{f}} \fallingdotseq 2.1$ 、CASE $\quad \mathrm{B}-2 \mathrm{C}^{\prime}\left(\mathrm{v}^{\prime 2}\right)^{0.5} / \mathrm{v} \fallingdotseq 0.063$ 、 $\mathrm{v} / \mathrm{V} \fallingdotseq 3.0 、\left(\mathrm{v}^{\prime 2}\right)^{0.5} / \mathrm{V}_{\mathrm{f}} \fallingdotseq 1.8$ であり、いずれの速度 比もB-2の方がやや大きいものの、ほぼ同様の值と なっている。以上の結果に基づくと、 $\left(\mathrm{v}^{12}\right)^{0.5} / \mathrm{V}_{\mathrm{f}}$ が $\fallingdotseq 2.0$ 程度であれば十分な乱れが発生し、落下粒子 群は乱流サーマルとして流動・拡散すると推察され る。ただし、今回の実験では投下量を変化させてい るわけではないので、 $\left(v^{i 2}\right)^{0.5} / \mathrm{V}_{\mathrm{f}}$ に関するこの值は さらに小さくなる可能性が残されている。この点に ついて今後の検討が必要である。

\section{4. まとめ}

本研究により以下のような結論が得られた。

(1) 粒子サーマル的落下形態における高濃度落下 粒子群では、 $\mathrm{H}^{*}=\mathrm{K}_{1 \mathrm{P}} \mathrm{z}^{*} 、 \mathrm{~B}^{*}=\mathrm{K}_{2 \mathrm{P}} \mathrm{z}^{*-2}$ およびV $=\mathrm{K}_{3 \mathrm{P}}$ $z^{*-1 / 2}$ なる関係が成立し、その特性は単相ブシネス クサーマル理論で記述できる。また、サーマル理論

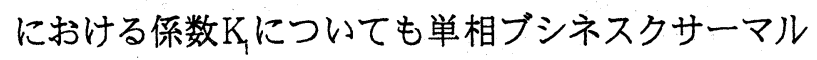
の関係が適用できる。ただし、両サーマルのK, 值は 異なっており、 $\mathrm{K}_{\mathrm{r}}$ 值の違いは $\mathrm{F}$ と $\mathrm{E}_{\mathrm{d}}$ の值の違いに起 因する。

（2）サーマル的な落下形態から自由沈降的な落下 形態への遷移が $/ \mathrm{V}_{\mathrm{f}} \fallingdotseq 1.0$ で起るとすると、これに 対応するZ゙は $Z^{*}{ }_{1.0} \fallingdotseq 900 \mathrm{R}_{\mathrm{p}}^{-4 / 3}$ なる関係を満足する。

(3)限定された条件下ではあるが、 $\left(\mathrm{v}^{\prime 2}\right)^{0.5} / \mathrm{V}_{\mathrm{f}} \fallingdotseq$

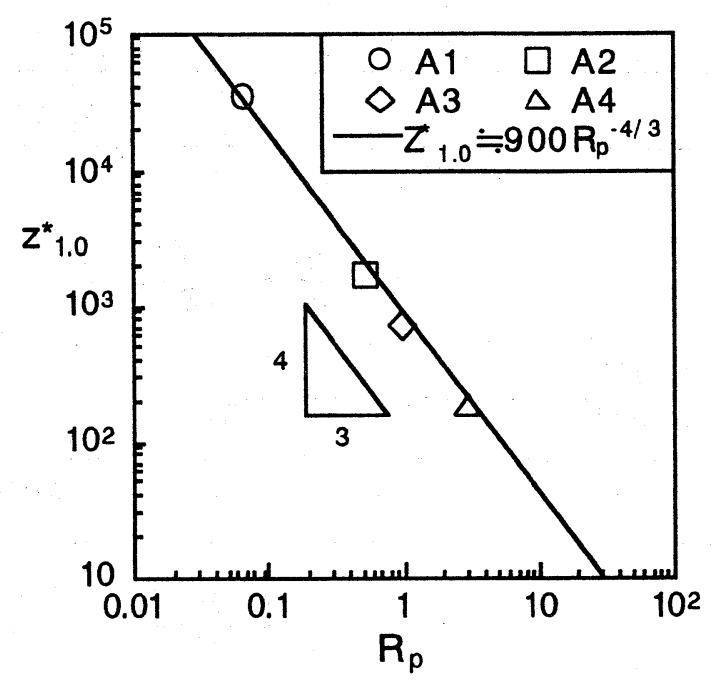

図-6 遷移点 $z_{1.0}^{*}$ と粒子Reynolds数 $\mathrm{R}_{\mathrm{p}}$ との関係

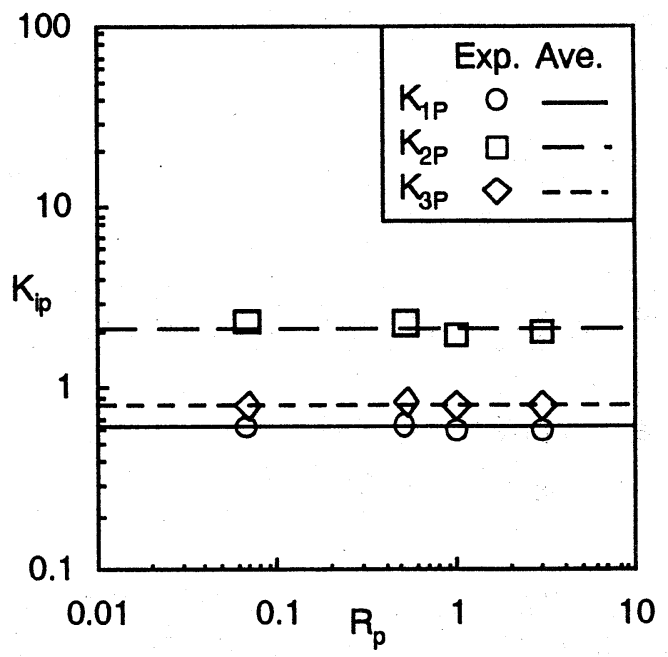

図-7 サーマル理論の係数 $\mathrm{K}_{\mathrm{ip}}$ と粒子Reynolds数

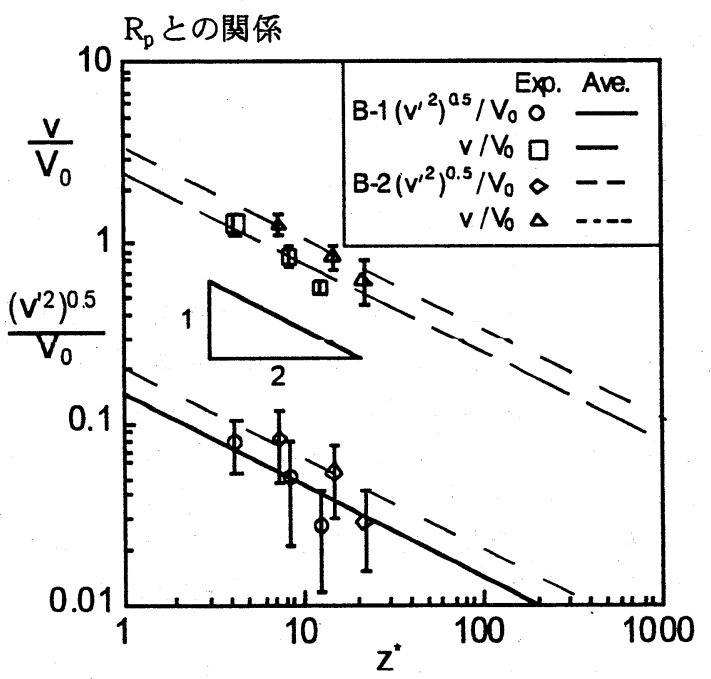

图-8 速度比 $v / V_{0} 、\left(v^{\prime 2}\right)^{0.5} / V_{0}$ と無次元落下距離 $z^{*}$ との関係

2.0 程度であれば十分な乱れが発生し、粒子群は乱 流サーマルとして落下する。このような乱れの強い 状態の落下粒子群ではサーマル理論の係数 $\mathrm{K}_{\mathrm{ip}}$ は粒 子Reynolds数R 
（補足）ブシネスク、非ブシネスクサーマル理論12),13)

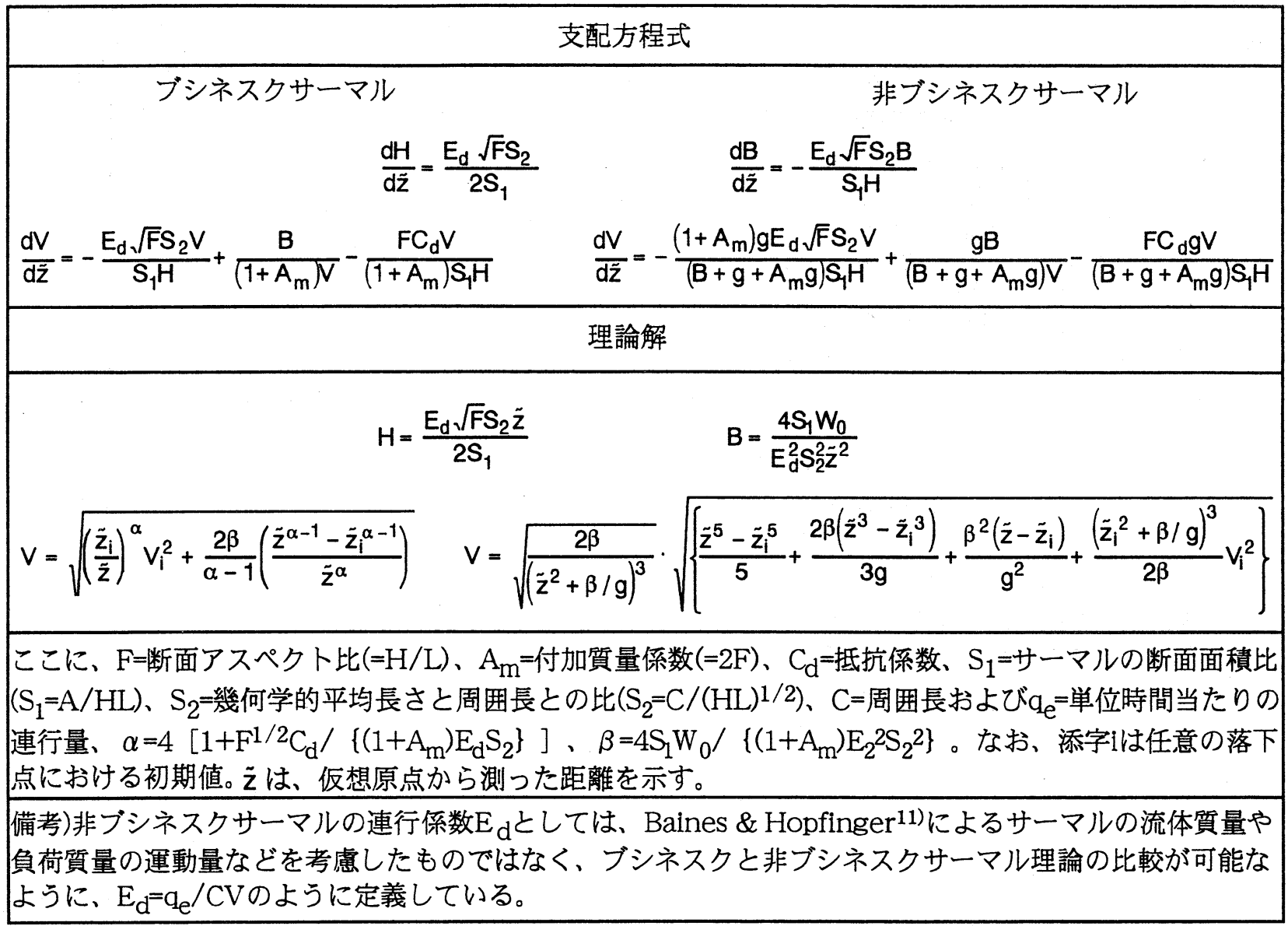

謝辞：本研究は、文部省科学研究費 (代表者 : 秋山 壽一郎、基盤(B) ( 2)、課題番号08455232および (B) (2)12555149) の援助を受けた。ここに記して 感謝の意を表します。

\section{参考文献}

1）堀江毅：MAC法による直投土砂の初期拡散に関する数 值解析、運輸省港湾技術研究所技術資料、No.471、 pp.1-34、1983.

2）小田一紀・重松孝昌・大西伸幸・井上雅夫： 改良型 DEMAC法による粒子群の沈降・分散挙動の解析、海 岸工学論文集、第39巻、pp.971-975、1992.

3) Li,C.W.:Convection of particle thermals, J. Hyd. Research, Vol.35, No.3, pp.363-376, 1997.

4）玉井昌宏・村岡浩爾 : 土砂直投工により発生する濁り の举動特性に関する数值解析、水工学論文集、第 42 巻、 pp.541-546、1998.

5) Ying.X., Akiyama,J. and Ura,M.: Motion of dense fluid released into quiescent water with finite depth, J. of Hydraulic, Coastal and Environmental Engineering, No.635/II-49, pp.141-152, 1999.

6) Buhler, J. \& Papantoniou, D.A. : Swarms of coarse particles falling through a fluid, Proc. of the Int Sym. on Envi. Hydraulics, Vol..1, pp.135$140,1991$.
7) Neves,M.J. \& Almeida,P.D. : The influence of density on thermal motion, Proc. of the Int'l Sym. on Envi. Hydraulics, Vol.1, pp.141-146, 1991.

8）玉井昌宏・村岡浩爾・室田明 : 固体粒子群の落下挙動 と誘起流動に関する研究、士木学会論文集、 No.509、II-30、pp.143-154、 1995.

9）秋山言一郎・浦 勝. 今宮盛雄・陶山正治 : 静水中に 瞬間的に投下された重たい流体塊の流動特性に関する 研究、水工学論文集、第42巻、pp.529-534、1998.

10) Escudier, M.P. \& Maxworthy, T. : On the motion of turbulent thermals, J. of Fluid Mech., Vol.61, Part 3, pp.541-552, 1973.

11) Baines, W.D \& Hopfinger, E.J. : Thermals with large density difference, Atomospheric Envi., Vol. 18, No. 6, pp.1051-1057, 1984.

12）秋山壽一郎・浦 勝・応 新严・西森秀樹: 流水中 に瞬間的に投下された重い流体塊の流動・抎散現象 に関する実験的研究、水工学論文集、第 42 巻、 pp.1165-1170、 1998.

13）陶山正治 : 直投粒子群の流動・抎散現象に関する研 究、修士論文、九州工業大学大学院、2000.

(2000.10.2 受付) 